
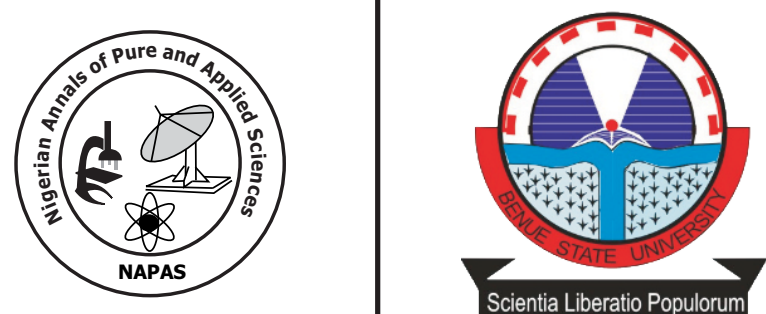

\title{
Morphometric and Meristic Characterization of Common Carp, Cyprinus Carpio Strains Sourced from Jos, Bauchi and Ibadan, Nigeria
}

\author{
Jacob, 0.0., Solomon, S. G., and Cheikyula, J.0. \\ Department of Fisheries and Aquaculture, \\ Federal University of Agriculture, Makurdi, Benue State. \\ *Corresponding author:owiochojacob@gmail.com
}

\begin{abstract}
The study investigated the morphometric and meristic characterization of Common carp (Cyprinus carpio) sourced from Jos Bauchi and Ibadan (Nigeria). In comparing the morphometric and meristic characters one hundred and eighty (180) adult Common carp, Cyprinus carpio were used. Twenty four (24) morphometric and six (6) meristic characters were studied. Measurements of the morphometric features were taken to the nearest centimeter by means of a measuring board, measuring rule, pair of dividers for the length, while the weight was taken by means of a weighing scale (salter scale) to the nearest gram. ANOVA, multivariate technique principal component analysis (PCA) and discriminant function analysis were also applied to the transformed morphometric data to; classify the fish into one or several mutually exclusive groups. The Morphometric study indicated that seven parameters did not differ significantly $(\mathrm{p}>0.05)$ between Jos (male and female), and Bauchi (male and Female) strains. The parameters are the body depth, caudal fin length, pectoral fin height, standard weight, pre dorsal distance, eye diameter and body weight. In the meristic count, only the dorsal fin spine did not differ significantly ( $p$ $>0.05$ ) among the Jos, Bauchi, and Ibadan strains in all sexes. The study revealed that there was a genetic distance between male and female Carp sourced from Ibadan and that of Jos and Bauchi, where as male and female Carp from Jos and Bauchi showed genetic closeness.
\end{abstract}

Key words: Common carp (Cyprinus carpio, morphometric, meristic, characterization 


\section{Introduction}

Morphological characters such as morphometric and meristic have been commonly used to identify fish stocks (Turan, et al., 2004) hence remains the simplest and most direct way among methods of species identification. From previous studies (Creech, 1992; Mamuris, et al., 1998; Bronte, et al., 1998; Hockaday, et al., 2000), it is understood that the analysis of phenotype variation in Morphometric characters or meristic counts is the method most commonly used to delineate stocks of fish, it is often being used in discrimination and classification studies by statistical techniques ((Agnew, 1988 and Avasar, 1994). Despite the advent of techniques which directly examine biochemical or molecular genetic variation, these conventional methods continue to have an important role in stock identification even to date (Swain and Foote 1999). The differences in the morphometric and meristic characters of a species between region may result from differences in genotypes, or environmental factors operating on one genotype, or both of these acting together. While both morphormetric and meristic characters respond to changes in environmental factors, their responses are different in some situation and may differ from species to species. The study of differences and variability in morphometric and meristic characters of fish stocks is important in phylogenetics and providing information for subsequent studies on the genetic improvement of stocks (Solomon et. al., 2015). Investigation of morphometeric variation particularly of meristic series, in wide ranging species of fishes has in many cases disclosed a lack of homogeneity with respect to certain characters in their racial studies of channel catfish (Ictalurus punctatus) from different geographical locations in the united states of America noticed highly significant difference between strains for all measurements except caudal peduncle width. Two of the wild strains, those with little or no inbreeding exhibited a large of degree variability with respect to those characteristics that could be potential use in selective breeding. Local adaptations of fish have for long been recognized to create great morphological variations (Turan et al., 2004). Pollar et al., (2007) reported that phenotypic plasticity of fish allows them to respond adaptively to environmental changes by modification of physiology and behavior which could lead to changes in their morphology, reproduction and survival that mitigate the effect of environmental variations.

\section{Aim and Objective}

The study attempted to investigate the morphometric and meristic differences between Common carp (Cyprinus carpio) sourced from Jos, Bauchi and Ibadan.

\section{Materials and methods Study Area}

The study was undertaken at the University of Agriculture, fish farm Makurdi. Makurdi, the Benue State capital (Nigeria) is located on the following geographical co-ordinates $7^{\circ} 44^{\prime} 0^{\prime \prime}$ North, $8^{\circ} 32^{\prime} 0^{\prime \prime}$ East.

One hundred and eighty (180) specimens made up of 30 males and 30 females of Cyprinus carpio germplasm from Jos, Bauchi and Ibadan were used in this study. Measurements of the following morphometric features were taken to the nearest centimeter by means of a measuring board, measuring rule, pair of dividers for the length while the weight was taken by means of a weighing scale (salter scale) to the nearest gram.

Total length (TL), Standard length (SL), Head length (HL), Standard weight (SW), Dorsal fin length (DFL), Anal fin length (AFL), Pectoral fin length (PFL), Pre-pelvic distance (PRE-PD), Pectoral spine length (PSL), Dis. Btw Occipital (DBW), Pre-dorsal distance (Pre-DD), Eye Diameter (ED), Body width(BW), Body depth (BD), Caudal peduncle(PD), Caudal fin length (CFL), Head width (HW), Head length (HL), Vomerine length (VL). Vomerine width (VW), Pectoral fin height (PFH), Anal fin height (AFH), Dorsal fin height (DFh), Snout length (SnL), Pre-orbital length (Pre-OL). The meristic features namely Anal fin ray (ANF), Dorsal fin ray (DFR) Caudal fin ray (CFR), Pectoral fin ray (PFR), Pelvic fin ray (PFR), were counted and recorded.

Statistical tools used were ANOVA, PCA (Principal Component Analysis) and discriminant Function Analysis.

\section{Results}

Seven parameters namely Body depth, caudal fin length , pectoral fin length, standard weight, predorsal distance, eye diameter and body weight showed no significant difference $(\mathrm{P}>0.05)$ between Bauchi ( male and female) and Jos (male and female). While two parameters namely, Eye diameter and body depth showed no significant difference (With $\mathrm{P}>0.05$ ) between Jos (male and Female) and Ibadan (male and female). While for Bauchi and Ibadan only the fin length showed no significant difference $(\mathrm{p}>0.05)$. 
Table 1: Mean Morphometric Measurements of Cyprinus carpio obtained from Jos, Bauchi and Ibadan

\begin{tabular}{|c|c|c|c|c|c|c|}
\hline Para & Bauchi ( Female) & Bauchi ( Male) & Jos ( Female ) & Jos (Male) & Ibadan ( Female) & Ibadan (Mal \\
\hline otal length $(\mathrm{cm})$ & $9.40 \pm 2.42^{b}$ & $46.85 \pm 2.15^{b}$ & $51.00 \pm 2.16^{\mathrm{ab}}$ & $54.35 \pm 2.15^{\mathrm{a}}$ & $29.88 \pm 0.19^{c}$ & $31.68 \pm 0.23^{c}$ \\
\hline Standard length $(\mathrm{cm})$ & $90 \pm 2.38^{\mathrm{ab}}$ & $7.95 \pm 1.99^{b}$ & $38.70 \pm 1.92^{\mathrm{ab}}$ & $43.05 \pm 2.06^{\mathrm{a}}$ & $24.40 \pm 0.19^{c}$ & $25.26 \pm 0.20^{\mathrm{c}}$ \\
\hline Standard weight(gm) & $999.00 \pm 104.00^{\mathrm{a}}$ & $953.50 \pm 86.30^{\mathrm{a}}$ & $1047.50 \pm 87.10^{\mathrm{a}}$ & $999.00 \pm 95.30^{\mathrm{a}}$ & a $363.30 \pm 10.9^{b}$ & $433.00 \pm 13.80^{\circ}$ \\
\hline Dorsal fin length & $11.92 \pm 0.57^{\mathrm{b}}$ & $13.62 \pm 0.58^{\mathrm{a}}$ & $12.78 \pm 0.45^{\mathrm{ab}}$ & $13.64 \pm 0.61^{\mathrm{a}}$ & $9.02 \pm 0.24^{\mathrm{c}}$ & $9.89 \pm 0.15^{\mathrm{c}}$ \\
\hline Anal fin length & $3.10 \pm 0.22^{\mathrm{b}}$ & $2.98 \pm 0.19^{\mathrm{b}}$ & $3.32 \pm 0.20^{\mathrm{ab}}$ & $3.59 \pm 0.18^{\mathrm{a}}$ & $2.07 \pm 0.03^{\mathrm{d}}$ & $2.55 \pm 0.07^{\mathrm{c}}$ \\
\hline Pectoral fin length & $2.49 \pm 0.14^{\mathrm{b}}$ & $2.52 \pm 0.13^{\mathrm{b}}$ & $3.11 \pm 0.15^{\mathrm{a}}$ & $3.04 \pm 0.15^{\mathrm{a}}$ & $1.72 \pm 0.04^{\mathrm{d}}$ & $2.00 \pm 0.05^{\mathrm{c}}$ \\
\hline Pelvic fin length & $1.88 \pm 0.11^{\mathrm{b}}$ & $1.80 \pm 0.09^{\mathrm{b}}$ & $2.67 \pm 0.14^{\mathrm{a}}$ & $2.96 \pm 0.19^{\mathrm{a}}$ & $1.64 \pm 0.06^{\mathrm{b}}$ & $1.87 \pm 0.06^{\mathrm{b}}$ \\
\hline Pre-pelvic distance & $14.14 \pm 0.77^{\mathrm{b}}$ & $16.07 \pm 0.66^{\mathrm{a}}$ & $15.93 \pm 0.69^{\mathrm{a}}$ & $15.53 \pm 0.69^{\mathrm{ab}}$ & $11.40 \pm 0.19^{c}$ & $11.93 \pm 0.21^{\mathrm{c}}$ \\
\hline Pectoral spine length & $4.88 \pm 0.23^{b c}$ & $4.94 \pm 0.15^{b c}$ & $4.40 \pm 0.21^{\mathrm{c}}$ & $5.19 \pm 0.17^{b}$ & $11.93 \pm 0.28^{\mathrm{a}}$ & $12.37 \pm 0.31^{\mathrm{a}}$ \\
\hline Dist. Btw Occipital & $12.89 \pm 0.60$ & $12.65 \pm 0.59$ & $13.28 \pm 0.56$ & $13.68 \pm 0.52$ & $13.08 \pm 0.02$ & $13.21 \pm 0.22$ \\
\hline Pre-dorsal distance & $16.02 \pm 0.62^{\mathrm{a}}$ & $15.68 \pm 0.67^{\mathrm{a}}$ & $16.50 \pm 0.56^{\mathrm{a}}$ & $16.56 \pm 0.54^{\mathrm{a}}$ & $9.96 \pm 0.21^{\mathrm{b}}$ & $10.55 \pm 0.24^{b}$ \\
\hline Eye Diameter & $2.62 \pm 0.87^{\mathrm{a}}$ & $2.44 \pm 0.82^{\mathrm{a}}$ & $1.53 \pm 0.09^{\mathrm{ab}}$ & $1.63 \pm 0.07^{\mathrm{ab}}$ & $1.14 \pm 0.03^{\mathrm{b}}$ & $1.25 \pm 0.02^{\mathrm{b}}$ \\
\hline Body width & $8.46 \pm 2$ & $6.11 \pm 0$ & $5.66 \pm 0.30^{\mathrm{ab}}$ & $5.81 \pm 0.24^{\mathrm{ab}}$ & $4.95 \pm 0.20^{\mathrm{b}}$ & $5.85 \pm 0.17^{\mathrm{ab}}$ \\
\hline Body Depth & $10.97 \pm 0.47^{\mathrm{a}}$ & $10.89 \pm 0$ & $11.50 \pm 0.48^{\mathrm{a}}$ & $11.54 \pm 0.65^{\mathrm{a}}$ & & $7.82 \pm 0.25^{\mathrm{b}}$ \\
\hline Caudal peduncle & $5.34 \pm 0.27^{\mathrm{ab}}$ & $4.84 \pm 0.28^{b}$ & $5.58 \pm 0.25^{\mathrm{a}}$ & $5.36 \pm 0.31^{\mathrm{ab}}$ & $2.94 \pm 0.07^{\mathrm{c}}$ & $3.34 \pm 0.08^{\mathrm{c}}$ \\
\hline Caudal fin length & $7.84 \pm 0.19^{\mathrm{a}}$ & $7.92 \pm 0.16^{\mathrm{a}}$ & $7.50 \pm 0.25^{\mathrm{a}}$ & $7.96 \pm 0.30^{\mathrm{a}}$ & $5.46 \pm 0.13^{c}$ & $6.37 \pm 0.15^{\mathrm{b}}$ \\
\hline Head Width & $6.16 \pm 0.34^{\mathrm{b}}$ & $7.18 \pm 0.37^{\mathrm{a}}$ & & $5.71 \pm 0.24^{\mathrm{b}}$ & $3.08 \pm 0.13^{c}$ & $4.35 \pm 0.15^{\mathrm{c}}$ \\
\hline Head length & $8.73 \pm 0.19^{a}$ & $9.38 \pm 0.42^{\mathrm{a}}$ & $7.55 \pm 0.34^{b=}$ & $7.89 \pm 0.22^{b}$ & $6.23 \pm 0.17^{\mathrm{c}}$ & $6.71 \pm 0.07^{\mathrm{c}}$ \\
\hline Vomerine length & $2.88 \pm 0.11^{\mathrm{b}}$ & $2.66 \pm 0.11^{b}$ & $3.37 \pm 0.14^{\mathrm{a}}$ & $3.33 \pm 0.09^{\mathrm{a}}$ & $2.03 \pm 0.03^{c}$ & $2.21 \pm 0.05^{\mathrm{c}}$ \\
\hline Vomerine Width & $2.98 \pm 0.09^{\mathrm{ab}}$ & $3.19 \pm 0.09^{\mathrm{a}}$ & $2.70 \pm 0.11^{\mathrm{c}}$ & $2.91 \pm 0.09^{b c}$ & $1.97 \pm 0.03^{\mathrm{d}}$ & $2.14 \pm 0.03^{\mathrm{d}}$ \\
\hline Pectoral fin height & $5.74 \pm 0.24^{\mathrm{a}}$ & $5.99 \pm 0.26^{\mathrm{a}}$ & $5.53 \pm 0.32^{\mathrm{a}}$ & $5.45 \pm 0.17^{\mathrm{a}}$ & $3.77 \pm 0.07^{b}$ & $4.04 \pm 0.08^{b}$ \\
\hline Anal fin height & $5.79 \pm 0.19^{b}$ & $6.51 \pm 0.15^{\mathrm{a}}$ & $5.08 \pm 0.27^{\mathrm{c}}$ & $5.44 \pm 0.16^{b c}$ & $2.87 \pm 0.08^{\mathrm{e}}$ & $3.38 \pm 0.09^{\mathrm{d}}$ \\
\hline Dorsal fin height & $6.10 \pm 0.22^{\mathrm{a}}$ & $6.37 \pm 0.25^{\mathrm{a}}$ & $5.45 \pm 0.26^{\mathrm{b}}$ & $6.04 \pm 0.19^{a}$ & $2.85 \pm 0.08^{\mathrm{d}}$ & $3.34 \pm 0.09^{\mathrm{c}}$ \\
\hline Snout length & $5.39 \pm 0.21^{\mathrm{a}}$ & $5.36 \pm 0.20^{\mathrm{a}}$ & $4.15 \pm 0.17^{\mathrm{c}}$ & $4.89 \pm 0.17^{\mathrm{b}}$ & $2.21 \pm 0.05^{\mathrm{d}}$ & $2.36 \pm 0.04^{\mathrm{d}}$ \\
\hline Pre -orbital length & $4.14 \pm 0.22^{b}$ & $4.68 \pm 0.19^{\mathrm{a}}$ & $3.25 \pm 0.20^{\mathrm{c}}$ & $3.22 \pm 0.06^{\mathrm{c}}$ & $3.98 \pm 0.12^{\mathrm{b}}$ & $1.46 \pm 0.05^{\mathrm{d}}$ \\
\hline
\end{tabular}

Mean in the same row with different superscript differ significantly $(\mathrm{P}<0.05)$

Only the Doral fin spine shows no significant difference ( $\mathrm{p}>0.05)$ across the strains from Jos, Bauchi and Ibadan, while the dorsal fin ray and pectoral fin ray for Bauchi and Jos strains did not show any significant difference( $p>0.05)$. Similarly, Anal fin ray and pelvic fin ray for Jos, and Ibadan did not show any significant difference $(\mathrm{p}>0.05)$.

Table 2: Mean Meristic Count of Cyprinus carpio from Jos, Bauchi and Ibadan

\begin{tabular}{lllllll}
\hline Parameters & $\begin{array}{l}\text { Bauchi } \\
\text { (Female) }\end{array}$ & $\begin{array}{l}\text { Bauchi } \\
\text { (Male) }\end{array}$ & $\begin{array}{l}\text { Jos } \\
\text { (Female })\end{array}$ & $\begin{array}{l}\text { Jos } \\
\text { (Male) }\end{array}$ & $\begin{array}{l}\text { Ibadan } \\
\text { (Female) }\end{array}$ & $\begin{array}{l}\text { Ibadan } \\
\text { (Male) }\end{array}$ \\
\hline Anal fin ray & $6.85 \pm 0.15^{\mathrm{a}}$ & $6.45 \pm 0.11^{\mathrm{b}}$ & $6.45 \pm 0.22^{\mathrm{b}}$ & $6.10 \pm 0.19^{\mathrm{bc}}$ & $6.00 \pm 0.00^{\mathrm{c}}$ & $6.00 \pm 0.00^{\mathrm{c}}$ \\
Dorsal fin ray & $20.75 \pm 0.22^{\mathrm{a}}$ & $20.20 \pm 0.20^{\mathrm{b}}$ & $20.65 \pm 0.21^{\mathrm{ab}}$ & $20.55 \pm 0.15^{\mathrm{ab}}$ & $17.60 \pm 0.11^{\mathrm{c}}$ & $17.83 \pm 0.11^{\mathrm{c}}$ \\
Caudal fin ray & $19.60 \pm 0.28^{\mathrm{a}}$ & $18.90 \pm 0.25^{\mathrm{b}}$ & $18.00 \pm 0.22^{\mathrm{c}}$ & $18.10 \pm 0.23^{\mathrm{c}}$ & $17.40 \pm 0.09^{\mathrm{d}}$ & $17.41 \pm 0.09^{\mathrm{d}}$ \\
Pectoral fin ray & $14.15 \pm 0.17^{\mathrm{a}}$ & $13.85 \pm 0.17^{\mathrm{ab}}$ & $13.55 \pm 0.21^{\mathrm{b}}$ & $13.45 \pm 0.19^{\mathrm{b}}$ & $11.97 \pm 0.09^{\mathrm{c}}$ & $12.00 \pm 0.09^{\mathrm{c}}$ \\
Pelvic fin ray & $8.75 \pm 0.25^{\mathrm{a}}$ & $8.05 \pm 0.19^{\mathrm{b}}$ & $7.80 \pm 0.19^{\mathrm{b}}$ & $7.80 \pm 0.19^{\mathrm{b}}$ & $8.00 \pm 0.00^{\mathrm{b}}$ & $8.00 \pm 0.00^{\mathrm{b}}$ \\
Dorsal fin spine & $1.00 \pm 0.00$ & $1.00 \pm 0.00$ & $1.00 \pm 0.00$ & $1.00 \pm 0.00$ & $1.00 \pm 0.00$ & $1.00 \pm 0.00$ \\
\hline
\end{tabular}

Mean in the same row with different superscript differ significantly $(\mathrm{P}<0.05)$ 


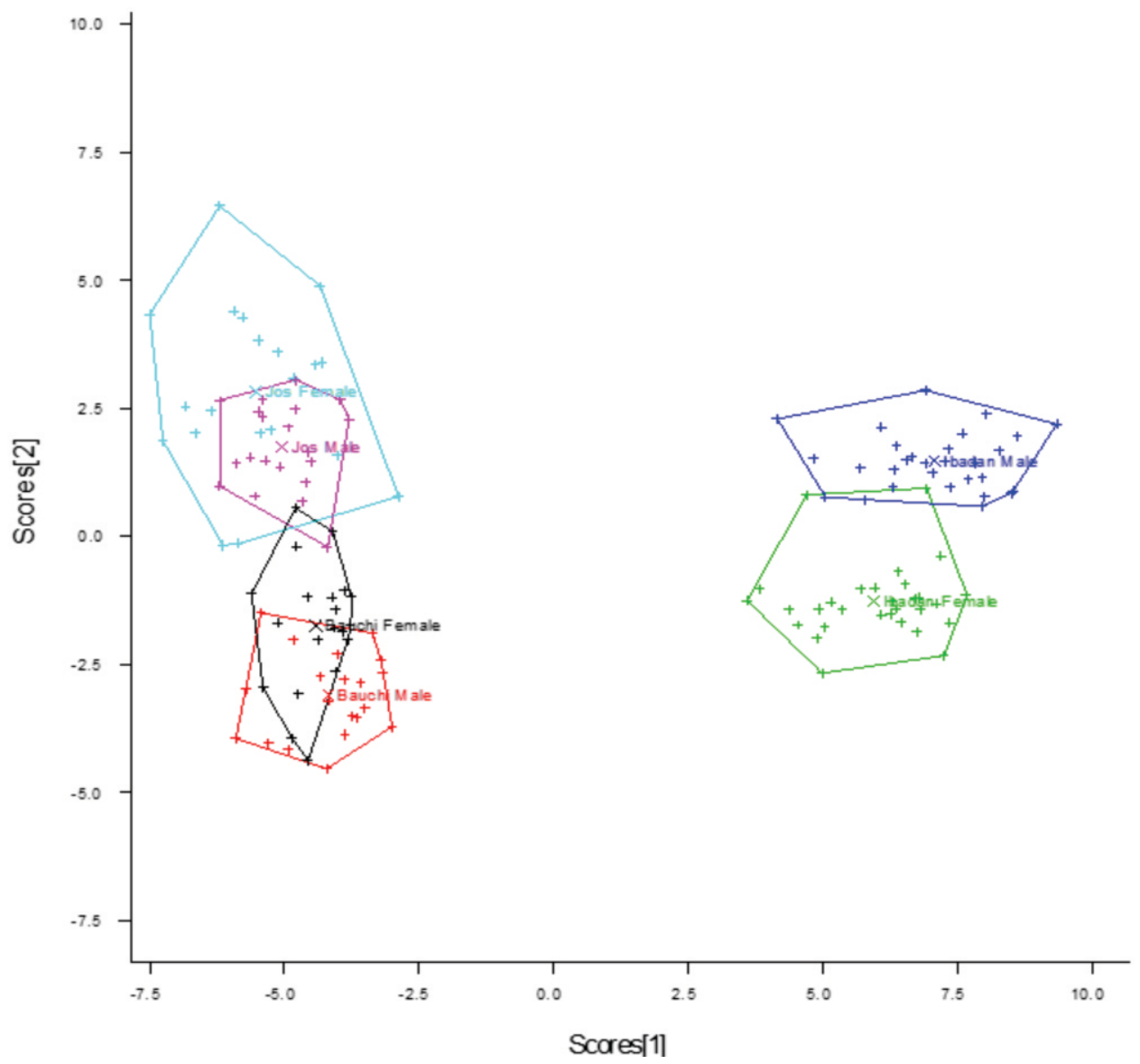

Fig.1:Sample centroids of the discriminant function scores based on morphometric measurements of cyprinus carpio from Jos, Bauchi and Ibadan

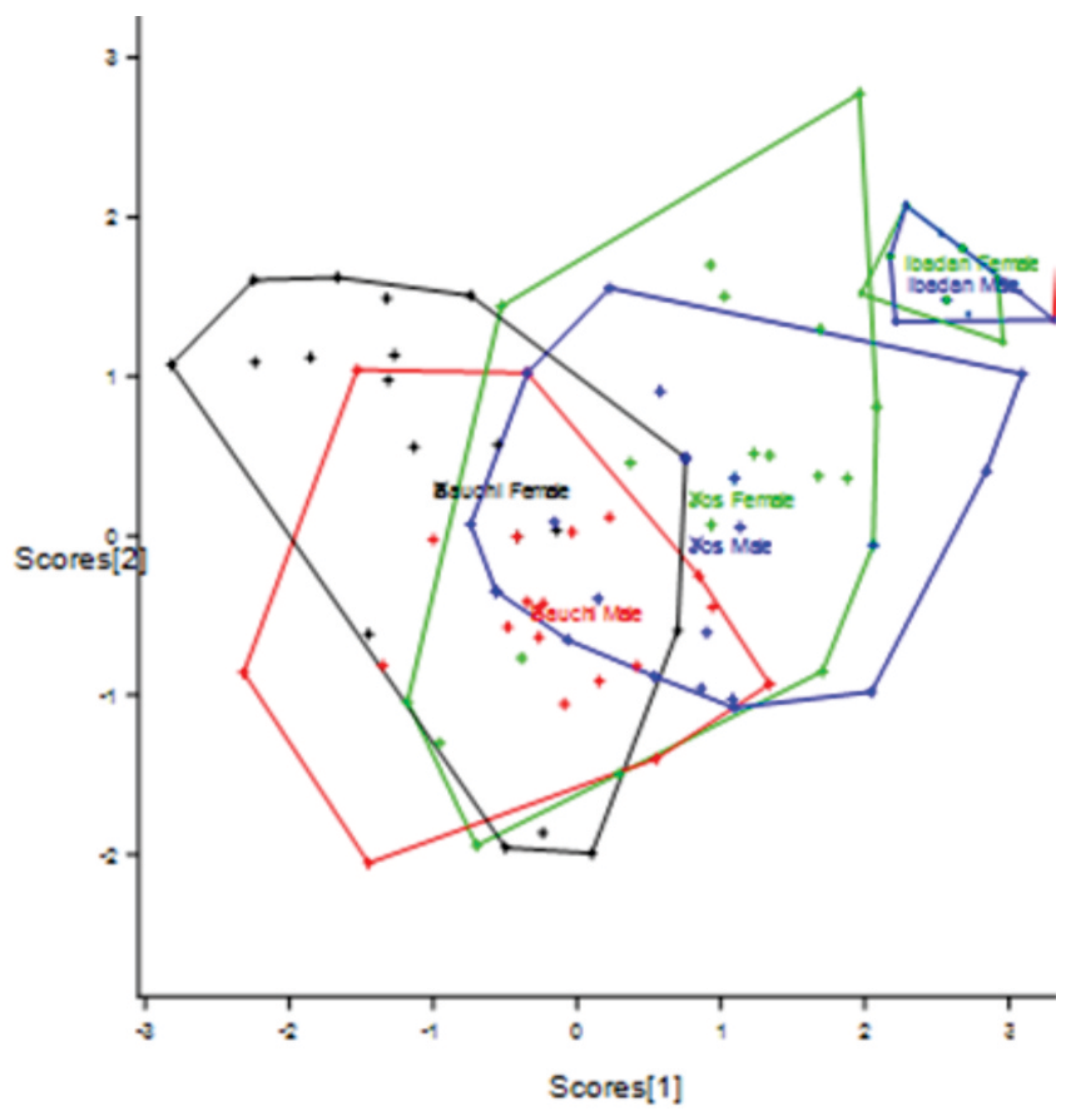

Fig. 2:Sample centroids of the discriminant function scores based on meristic count of cyprinus carpio from Jos, Bauchi and Ibadan. 


\section{Discussion}

The Morphometric study indicated that seven parameters namely Body depth, Caudal fin length, pectoral fin height, standard weight, pre dorsal distance, eye diameter and body width did not differ significantly between Jos (male and female), and Bauchi (male and Female) strains. However, two parameters namely eye diameter, body width did not differ significantly between Jos (male and female) and Ibadan (male and female) while for Bauchi (male and female) and Ibadan (male and female) only the pelvic fin length showed no significant difference. The meristic count, only the dorsal fin spine did not differ significantly among the Jos, Bauchi, and Ibadan strains in all sexes. The dorsal fin ray and pectoral fin ray for Bauchi and Jos did not differ significantly. The observations in this study are in line with earlier work done by Lowe-Mc Connem (1982) that when the same species introduced into different water bodies often respond in an unpredictable manner depending on the prevailing environmental characteristics. This variability may be due to geographical isolation, phenotypic plasticity and local adaptation. The discriminant function scores for the morphometric shows an overlap between the Jos and Bauchi strains an indication that the two strains are genetically closely related while the Ibadan strain exhibited a genetic distance from these two strains. While the discriminant function scores for the meristic count indicated genetic close relationship. The morphological differences among stocks observed in this study could be linked to differences in geographical and ancestral origins as observed by (Hossain et al., 2010). However, all the carp studied from the different environments possessed one dorsal fin spine which is contrary to Froeses and Pauly (2011) who stated that common carp had one long dorsal fin which possesses 2-3 hard and 17-22soft rays. El Serafy et al (2007) also stated that hybridization through extensive intra breeding was a possible cause of morphological variation. The variations in this study, is affirmed by (Allendorf et al., 1987, Wimberger 1992) that observed, that fish is most susceptible to environmentally induced morphological variations; hence demonstrate greater variances within and between populations than any other vertebrates. Pollar et al., (2007) reported that phenotypic plasticity of fish allowed them to respond adaptively to environmental changes by modification of physiology and behavior which could lead to changes in their morphology, reproduction and survival that mitigate the effect of environmental variations.

\section{Conclusion}

The study showed that Common carp sourced from Jos, Bauchi and Ibadan varied in some morphometric characteristics while the meristic characteristics tend to overlap among the Common carp from all the sources.

\section{Acknowledgement}

The author is grateful to West Africa Agricultural Productivity Programme (WAAPP) that funded the Carp project under the competitive Agricultural Research grant Scheme won by Prof. S.G. Solomon.

\section{References}

Agnew, D.J. (1988). Evidence for the existence of two populations of Irish seacod (Gadus morhua L) from consideration of growth rate ICESCM/G: Dermensal fish committee. $19 \mathrm{pp}$

Allendorf, F. W., Rayman, N., Utter, F. (1987). Genetrics and fishery management, past, present and future in population genetrics and fisheries management Seattle, WA and London: University of Washington Press, pp 1-20.

Avasar, D. (1994). Stock differentiation study of the sprat off the southern coast of the Black sea. Fisheries Research, 19:363-378.

Bronte, C.R., Fleischer, G.W Pronin, N.M (1998) Stock structure of Lake Baikal omul as cetermined by whole body morphology. Journal of Fisheries Biology 54:787-798.

Creech, S. (1992) A multivariate morphometric investigation of Atherina boyeri Risso. 1810 and A. presbyter cuvier 1829 (Teloostei; Atherinidae) morphometric evidence in support of the two species. Journal of Fisheries biology 41:341-353.

El Serafy, S. S., Abdel-Hamide, N.A.H., Awward, H.M., Azab, M.S. (2007). DNA rib printing analysis of Tilapia species and their hybrids using restriction fragment length poly morphisms of the small sub unit ribosomal DNAAgran Research. 38: 295-303.

Froese, R. and Pauly, D. (eds.). (2011). Fish Base. World Wide Web electronic publication, version (02/2011) (available at: w w w . fi s h b a s e.org/s u m mary /speciessummary.php;

Hockaday, S., Beddow, T.A Stone, M., Hancock, P., Ross, L. G (2000) Using truss networks to estimate the biomass of Oreochromis niloticus and to investigate shape characters. Journal of fisheries Biology 57: 981-1000.

Hossain, M. A.R., Nahlduzzaman, M.D., Saha, D. 
Habiba Khanam, M.U., Alam, M.S.(2010). Land mark - Based morphometric and meristic variations of the endangered carp, Kalibaus Labeo calbasu from stocks of two isolated rivers the Jarnona and Halda, and a hatchery Zoological studies 49(4):556-563

Lowe McConnell, R .H (1982) Tilapia in fish communities, In R.S.V.Pullin and R. H. Lowe McConnell (eds). The Biology and culture of Tilapia. ICLARM conference proceeding 7, 83-113, Manila Philippines.

Mamuris, Z., Apostolidis P., Theodorou, A.J., Triantaphllidis, C. (1998) Morphological variation between mullet populations in Greece. Journal of Fisheries Biology 52, 107-117.

Pollar, M. Jaroeensutasinee $M$ and $K$ Jaroensutasinee (2007). Morphometric analysis of Tor tambroides by stepwise Discriminant and Neural Network Analysis.
Proceedings of World Academy of science, Engineering and Technology 21: 13076994.

Solomon, S.G., Okomoda, V.T., Ogbenyikwu, A. I. (2015). Intraspecific Morphological Variation between Cultured and wild Clarias gariepinus (Burchell) (Claridae, $\begin{array}{lllllllllllll}\mathrm{S} & \mathrm{i} & 1 & \mathrm{u} & \mathrm{r} & \mathrm{i} & \mathrm{f} & \mathrm{o} & \mathrm{r} & \mathrm{m} & \mathrm{s} & \text { ) }\end{array}$ www.infish.com.p1/wydawinictwo/Archiv es/Fasc/work.pdf/.o/Vol23Fasc1-wobpdf.

Swain, D. P., Foote, C. J. (1999). Stocks and Chameleons the use of Phenotyypic variation in Stock identification. Fisheries Research 43: 113 - '28.

Turan, C., Erguden, D. Turan, F., Gurlek, M. (2004). Genetric and Morphology C. Structure of Liza abu (Heckel, 1843). Populations from the Rivers Crontes, Eurphrates and Tigers Turkish Journal of veterinary Animal Science 28:729-734. 